\title{
Suitability of Parkinsonia aculeata (L.) Wood Grown as an Architectural Landscape Tree in North Darfur State for Interior Design and Furniture
}

\section{Osman Taha Elzaki}

1 Institute of Engineering Research and Materials Technology, NCR, Khartoum, Sudan

Nawal Ibrahim Idris

Institute of Engineering Research and Materials Technology, NCR, Khartoum, Sudan

Mohamed Elsanosi Adam Habib

2University of Al Fashir; Faculty of Environmental Sciences and Natural Resources

Tarig Osman Khider ( $\square$ tarigosmankhider@gmail.com )

University of Bahri, College of Applied and Industrial Sciences, Khartoum, Sudan

https://orcid.org/0000-0003-4494-8402

\section{Research Article}

Keywords: Parkinsonia aculeata , Architectural landscape, Basic density, Static Bending, Compressive Strength

Posted Date: July 14th, 2020

DOl: https://doi.org/10.21203/rs.3.rs-40962/v1

License: (c) (1) This work is licensed under a Creative Commons Attribution 4.0 International License. Read Full License 


\section{Abstract}

Wood samples of Parkinsonia aculeata (L.) were collected from Al bohaira Gardens of Al Fashir Town (the capital of North Darfur State, Western Sudan) where they were planted as architectural landscape trees and studied to determine their physical and mechanical properties as potential wood species for structural and furniture purposes. Moisture content, wood density (basic and oven-dry), as well as radial and tangential shrinkage were determined. The mechanical properties studied included static bending strength, compression strength parallel to the grain, the modulus of elasticity (MOE), the modulus of rupture (MOR), and the maximum crushing strength. The obtained results were compared with those of the well-known dominant small hardwood tree in the same area (Boscia senegalensis). The wood of P. aculeata has shown medium oven-dry density $\left(534.0 \mathrm{~kg} \mathrm{~m}^{-3}\right)$ with reasonable bark-to-wood and shrinkage ratio. Due to the acceptable bending and compression strength results, $P$. aculeata wood can be considered as a suitable wood for interior design and decoration work as well as its suitability for indoor furniture.

\section{Introduction}

Parkinsonia aculeata L. (Jerusalem - thorn) is a small tree or sometimes a shrub which can reach up to 10 meters high (Figure 1). It belongs to the family Fabaceae and subfamily Caesalpinioideae [1-5]lt is native to tropical and subtropical America in Southern USA and Northern South America [6 \&7]. It occurs in nearly all semi-arid tropical countries. It can withstand drought and salinity. This multi-trunked deciduous tree has a green bark, pendulous branch-tips with bipinnate leaves, delicate leaflets and yellow blooms with pleasant fragrance. Those characters made it a popular small landscape tree especially in arid regions [8] where the free landscape design plans developed by professional landscape architects exclusively focuses on trees and shrubs. P. aculeata trees are used as street trees or road-side trees (Figure 2) and parking lots (Figure 3 ) so architects use it in their architectural landscape designs in hot arid regions. They use it as anchors for garden beds and as an architectural accent plant for the corner of the house or panted as a single specimen tree [9]. The tree is also used as windbreak and impenetrable hedges in gardens and parks [3]. The wood is yellowish white in color. It is used as low grade fuel wood. The tree provides fodder for sheep and goats. The leaves, seeds, flowers, and bark are used in traditional medicine [10\&11]. Many pharmacological studies and investigations were carried out recently on the different parts of the tree as a medicinal plant [8\&12].

The use of this wood species is restricted to fuel wood and charcoal. In order to make the best utilization and add value to the wood of this landscape tree, this study was carried out aiming at the Investigation of the physical and mechanical, properties of this hardwood species and to provide information relating to wood properties which lead to its best utilization as structural and inter design or furniture wood.

\section{Materials And Methods}


The materials used in this study are wood specimens of Parkinsonia aculeata collected from Albohaira Gardens of Al Fashir Town (the capital of North Darfur State, Western Sudan) The trees were planted as architectural landscape trees at the boundaries of the park in the form of life hedge.

\section{Methods}

Five logs from five randomly selected trees were collected, debarked and crosscut. Wood samples were prepared and reduced into testing specimens according to the British standards B.S. 373, 1957[13].

\section{Moisture content}

Moisture content of wood was determined using a sensitive balance and an oven maintained at $105^{\circ} \mathrm{C}$. The specimens were dried to constant weight. The moisture content was calculated as follows:

$$
\text { M. } C \%=\frac{A-B}{B} \% \cdots \cdots \cdots \cdots \cdots \cdots \cdots \cdots \cdots \cdots \cdots \cdots \cdots \cdots \cdots \cdots \cdots \cdots
$$

Where: A= Air-dry weight of specimen, B=Oven-dry weight of specimen, M.C. = Moisture content.

\section{Wood density}

Wood density was carried out using water displacement system. The basic density was determined as oven-dry weight / green volume, while the oven-dry density was determined as oven-dry weight / oven-dry volume. Both oven-dry density and basic density were calculated by the following equations:

$$
\begin{aligned}
& \text { Oven }- \text { dry Density }=\frac{\text { oven }- \text { dry weight }}{\text { oven }- \text { dry volume }} \mathrm{kgm}^{-3} \\
& \text { Basic Density }=\frac{\text { oven }- \text { dry weight }}{\text { oven }- \text { dry volume }} \mathrm{kg} \mathrm{m}^{-3}
\end{aligned}
$$

\section{Bark-to-wood ratio}

Bark-to-wood ratio was determined as a proportion of the whole tree (including bark) both by volume and by mass. Wood discs $\left(2.5 \mathrm{~cm}\right.$ thick) were cut, weighed and dried to constant weight in an oven at $105^{\circ} \mathrm{C}$. The bark and wood were weighed separately and from their masses the percentage of bark was calculated based on the oven-dry mass of the original test sample as follows: 


$$
\text { Bark }- \text { to }- \text { wood ratio }=\frac{\text { mass of oven }- \text { dry bark }}{\text { mass of oven }- \text { dry wood }}
$$

Wood shrinkage

Wood shrinkage was determined using wood specimens of $2 \mathrm{~cm} \times 2 \mathrm{~cm} \times 2 \mathrm{~cm}$ Measured with a Vernier caliper. The specimens were left to dry in an oven until constant weight, then they were measured again and the difference in dimensions was calculated as shrinkage ratio as follows:

$$
\text { Shrinkage } \%=\frac{\text { change in dimension from swollen size }}{\text { swollen dimension }} \times 100
$$

Bending strength

Static bending tests were carried out using a universal testing machine Specimens of $2 \mathrm{~cm} \times 2 \mathrm{~cm} \times 30 \mathrm{~cm}$ size were supported over a span of $28 \mathrm{~cm}$ on the roller bearings. The load was applied to the center of the beam at a speed of $0.01 \mathrm{~mm} /$ second. The modulus of elasticity and the modulus of rupture were recorded.

Compression strength

Compression strength parallel to the grain tests were carried out using specimens of $2 \mathrm{~cm} \times 2 \mathrm{~cm} \times 6 \mathrm{~cm}$ size. The tests were carried on a universal testing machine. The load was applied to the piston of the cage at a rate of $0.01 \mathrm{~mm}$ per second. The maximum crushing strength ( $\mathrm{P}$ max) was calculated by dividing the load to failure by the cross sectional area of the specimen as shown in the following equation:

$$
\text { Comp. sterngth }=\frac{P \max }{A} \mathrm{Kpa} \mathrm{m}^{-2}[4] \uparrow
$$

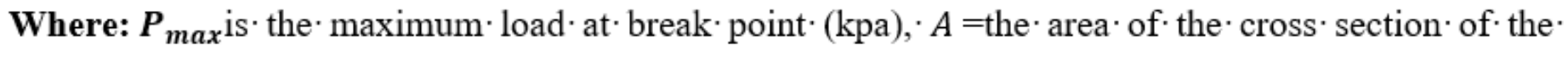
specimen. $\uparrow$

\section{Results And Discussion}

Physical and morphological properties 
The mean values of physical properties for $P$. aculeata from North Darfur state are shown in Table 1 . The values of moisture content for $P$. aculeata was nearly the same as that of $B$. senegalensis $(5.95 \%$ and $5.25 \%$ respectively). This is because they were from the same dry origin where the surrounding atmosphere has low relative humidity.

Although the average oven-dry density and basic density for $P$. aculeata $\left(534.0 \mathrm{~m}^{-3}\right.$ and $448.0 \mathrm{~m}^{-3}$, respectively) were lower than those for $B$. senegalensis but it is considered as a moderate density wood. This is a good property which indicates good or reasonable strength properties.

The average value of bark-to- wood ratio for P. aculeata (4.78\%) was found to be lower than that for $B$. senegalensis $(10.75 \%)$. This is good in debarking and peeling processes.

The tangential shrinkage (Table 2) was almost double the radial shrinkage (3.61and $8.46 \%$ ) This is very normal as cited by Desch and Elzaki [14-18]. The ratio for tangential to radial shrinkage (T/R) was higher for $P$. aculeata (2.68) compared with that for $B$. senegalensis (1.80).

Table 1. Average values for moisture content and bark-to-wood ratio for Parkinsonia aculeata wood compared with Boscia senegalensis wood

\begin{tabular}{lcc}
\hline Properties & P. aculeata & B. senegalensis \\
\hline Average moisture content. \% & 5.59 & 5.25
\end{tabular}

\begin{tabular}{lll} 
Average Bark-to-wood ratio by volume \% & 4.78 & 10.75 \\
\hline
\end{tabular}

Table 2. Average values of oven-dry density and basic density for Parkinsonia aculeata wood compared with Boscia senegalensis wood.

\begin{tabular}{lcc}
\hline Properties & P. aculeata & B. senegalensis \\
\hline Average oven-dry density kg m${ }^{-3}$ & 534.0 & 752.0 \\
Average basic density $\mathrm{kg} \mathrm{m}^{-3}$ & 448.0 & 646.0 \\
\hline
\end{tabular}

Table 3. Average values for important ratios of physical properties for Parkinsonia aculeata wood compared with those for Boscia senegalensis wood.

\begin{tabular}{lrr}
\hline Property ratio & P. aculeata & $B$. senegalensis \\
& & 3.89 \\
Average radial shrinkage \% & 3.61 & 5.98 \\
Average tangential shrinkage \% & 8.46 & 1.80 \\
\hline Average shrinkage ratio T/R & 2.68 & \\
\hline
\end{tabular}

Mechanical Properties 
Table 4. Average values for static bending tests for wood specimens of $P$. aculeata compared with B. senegalensis:

\begin{tabular}{llll}
\hline Species & $\mathrm{P}_{\max }(\mathrm{kN})$ & $\mathrm{MOR} \mathrm{MPa} \mathrm{cm}$ & $\mathrm{MOE} \mathrm{kPa} \mathrm{cm}$ \\
& & & \\
\hline P. aculeata & 1.862 & 68.786 & 8180.979 \\
B. senegalensis & 2.206 & 102.159 & 9131.497 \\
\hline
\end{tabular}

Table 5. Average values for compression strength parallel to the grain tests for wood specimens of $P$. aculeata compared with B. senegalensis:

\begin{tabular}{llll}
\hline Species & P max $(\mathrm{KN})$ minimum & P max $(\mathrm{KN})$ maximum & P max $(\mathrm{KN})$ Average \\
\hline P. aculeata & 25.440 & 29.900 & 27.217 \\
B. senegalensis & 20.690 & 33.290 & 26.002 \\
\hline
\end{tabular}

Table 2 showed the average values of the modulus of elasticity and modulus of rupture due to the static bending tests for $P$. aculeata in comparison with $B$. senegalensis. The values for both modulus of rupture (MOR) and the modulus of elasticity (MOE) for $P$ aculeata (68.786 MPa and $8180.979 \mathrm{kPa}$ ) were lower than those for $B$. senegalensis (102.159 MPa, and $9131.497 \mathrm{kPa}$, respectively). This variation may be due to the difference in the anatomical structures and mainly to indicators such as fiber length and cell wall thickness as well as an important physical parameter such as the wood density as cited by [15-19].

Table 3 shows the results of compression strength parallel to the grain for $P$. aculeata in comparison with $B$. senegalensis. $P$. aculeata has shown a bit higher average $P$ max than that for $B$. senegalensis. This is good for tool handles and other wooden parts which need resistance for compression forces and could be used for a wide range of both indoor and outdoor furniture. This strength of $P$. aculeata wood is considered a real plus-point for furniture designers, and give them a wider range of choice in furniture types than in many other wood species.

\section{Conclusion}

From the physical and morphological results in addition to the highest MOE and MOR as well as the maximum crushing strength, and in comparison with the well-known hardwood species, P. aculeata wood could be considered as a good timber with good strength properties which are preferred by interior designers and make them consider it as a suitable wood species for inter-design works, and indoor furniture.

\section{Declaration}

\section{Availability of data and materials}

We have already included all of data in the manuscript. 


\section{Consent for publication}

Not applicable.

\section{Ethics approval and consent to participate}

Not applicable.

\section{Funding}

Not applicable.

\section{Competing interests}

The authors declare no competing interests.

\section{References}

[1]Maydell, H. J. Von. 1990. Trees and Shrubs of the Sahel: Their Characteristics and Uses. GTZ Verlagjosefmargraf Scientific books

[2]El amin, M. H1990.Trees and Shrubs of the Sudan. Ithaca press, UK: 484pp.

[3] Woods W. 1992. Phytophagous insects collected from Parkinsonia aculeata (Leguminosae: Caesalpiniaceae) in the Sonoran desert region of the southwestern United States and Mexico. Entomophaga. 37 (3),465 -474

[4] Swarbrick JT, 1997. Weeds of the Pacific Islands. Technical paper No. 209. Noumea, New Caledonia, South Pacific Commission.

[5]Fournier, L. A. 2004. Parkinsonia aculeata L. Tropical Tree Seed, Manual. Part-2. Species Descriptions. pp: $597-598$

[6] Starr F, Starr K, Loope L, 2003. Parkinsonia aculeata. Plants of Hawaii reports.

[7] Carsan, S., Orwa, C., Hardwood, C. Kindant, R., Strobel, A, and Jamnadass, R. 2012. African wood Density data base. World Agroforestry Center, Nirobi.

[8]Divya, B. , Mruthunjaya, K., and Manjula, S. N. 2011. Parkinsonia aculeata: A pharmacological Review. Asian Journal of Plant Sciences. 10 (3): 175 - 181.

[9]Chase Landre 2012. Snowbird Gardening: A Guide For South Florida's Winter Residents. Planthead Publishers 
[10] Baumer, M. 1983. Trees and Shrubs of Arid and Semi-arid Regions. FAO, Rome. 270 pp.

[11]Baja, Y. 1988. Medicinal and Aromatic Plants. In:Biotechnology in Agriculture and Forestry, p24.

[12]Ali, M.S., F. Ahmed, M.K. Pervez, I. Azhar, and S.A. Ibrahim 2005. Parkintin: A new flavonone with epoxy-isopentyl moity from Parkinsonia aculeata Linn (Caesalpiniaceae). Nat. Prod. Res., 19 : 53 - 56.

[13] B. S. 373 1957. The British Standard Methods of Testing Small clear Specimens of Timber. British Standards Institute, London

[14] Desch, H.E., J. M., Dinwoodie, 1996. Timber, Structure, Properties, Conversion, and Use. ${ }^{\text {th }}$ ed. Macnillon Press, London, UK,.306pp.

[15] Elzaki, O. T. Otuk, S and Khider, T. 2013. Strength Properties of Crateva adansnii from Sudan. Journal of Forest Products \& Industries, 1(1), 23 - 26.

[16] Elzaki , O.T. Khider, T.O 2013. Physical and Mechanical Properties of Cupressus Iusitanica as a Potential Timber Tree for Sudan. Journal of Forest Products \& Industries, 2013, 2(1), 43-46

[17] Elzaki, O.T. Khider, T.O. 2013. Strength Properties of Ailanthus Excelsa Roxb.(Tree of Heaven) from Western Sudan. Journal of Applied and Industrial Sciences, 1 (2): 38-40

[18] Elzaki , O.T. Khider , T.O. 2013. Physical and Mechanical Properties of Pinus Radiata from Jebel Marra Western Sudan. Journal of Forest Products \& Industries, 2013, 2(3), 53-57.

[19] Elsanosi ,M .A. Elzaki,O.T and Mohiedin.S.D. 2015. Physical and Mechanical properties of five Sudanese hardwood species as potential timber trees for North Darfur State and Sudan. Journal of AlFashir University For Applied Sciences. Issue No. (6), 29 - 50.

. 7: $1046-1057$.

\section{Figures}




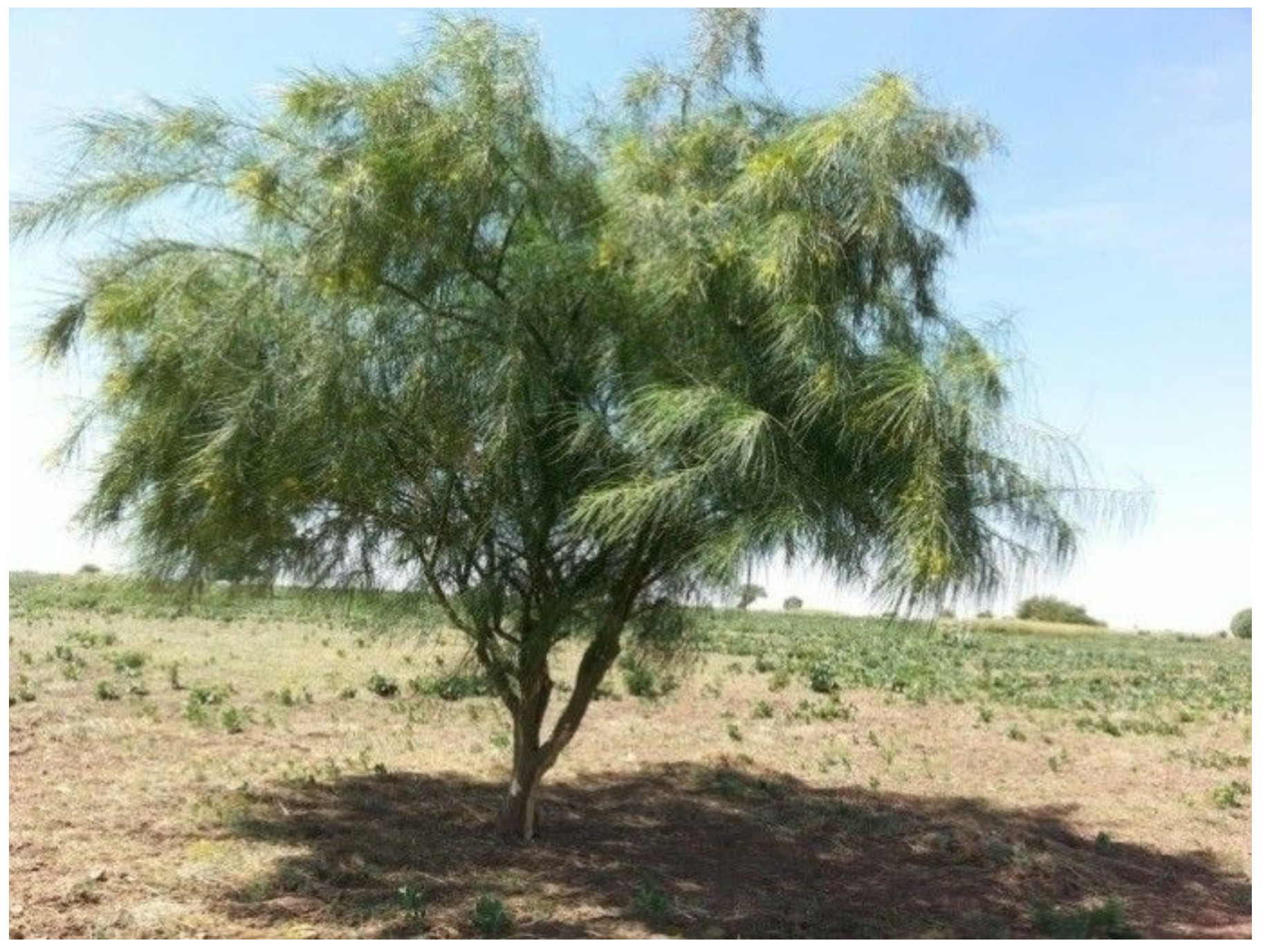

Figure 1

Parkinsonia tree growing at North Darfur State 


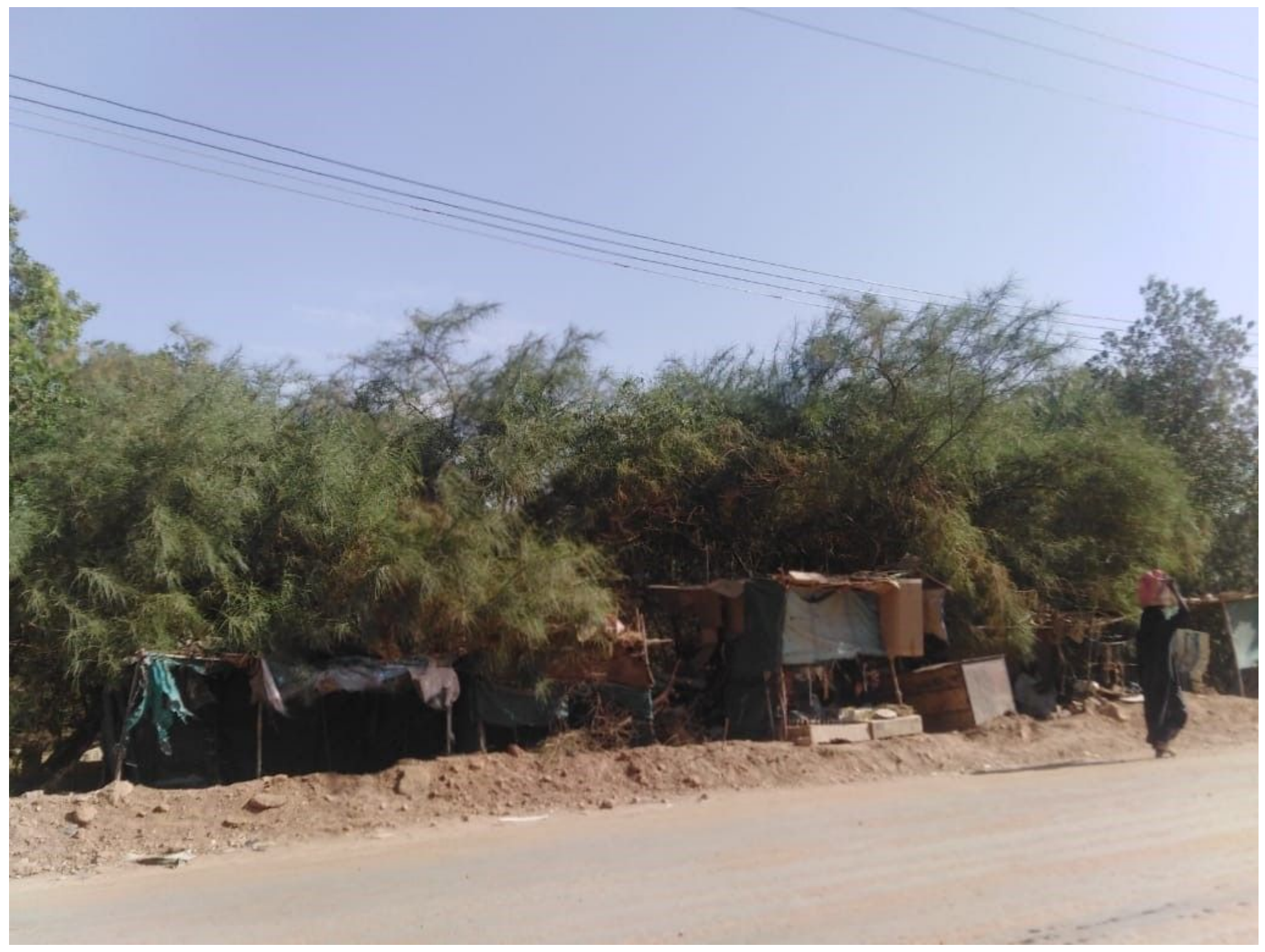

Figure 2

Parkinsonia tree planted as road-side tree in AlFashir town, North Darfur State, Sudan. 


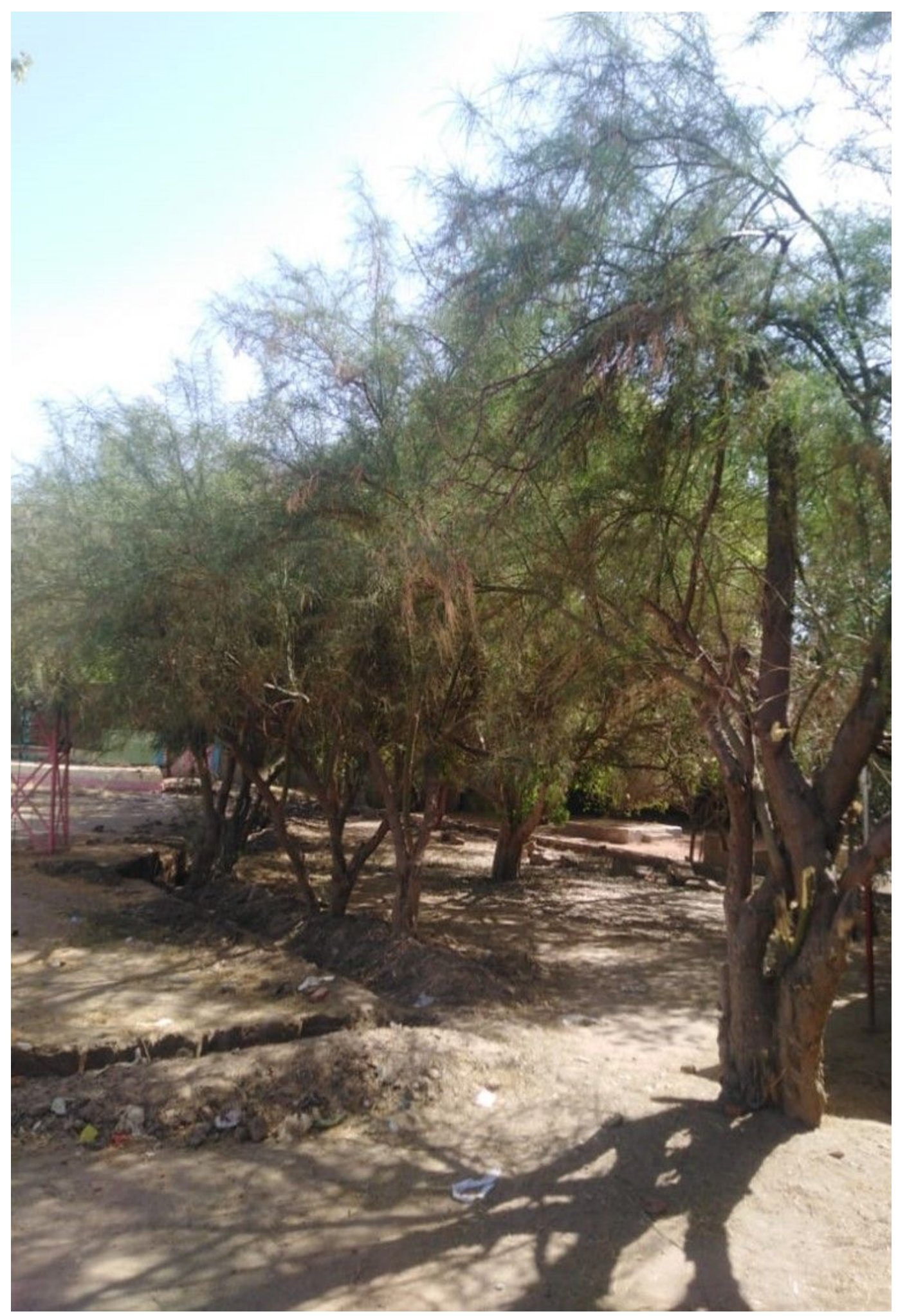

Figure 3

Parkinsonia tree planted in Albohaira Park, AlFashir town, North Darfur State, Sudan. 